\title{
GLIMPSES OF ARMY LIFE FROM WITHIN FROM 1860 TO 1895
}

\author{
WILLIAM MORRISON, J.P. \\ Honorary Captain and Quartermaster, Army Medical Service \\ (Lieutenant of Orderlies 1879-1881)
}

(Continued)

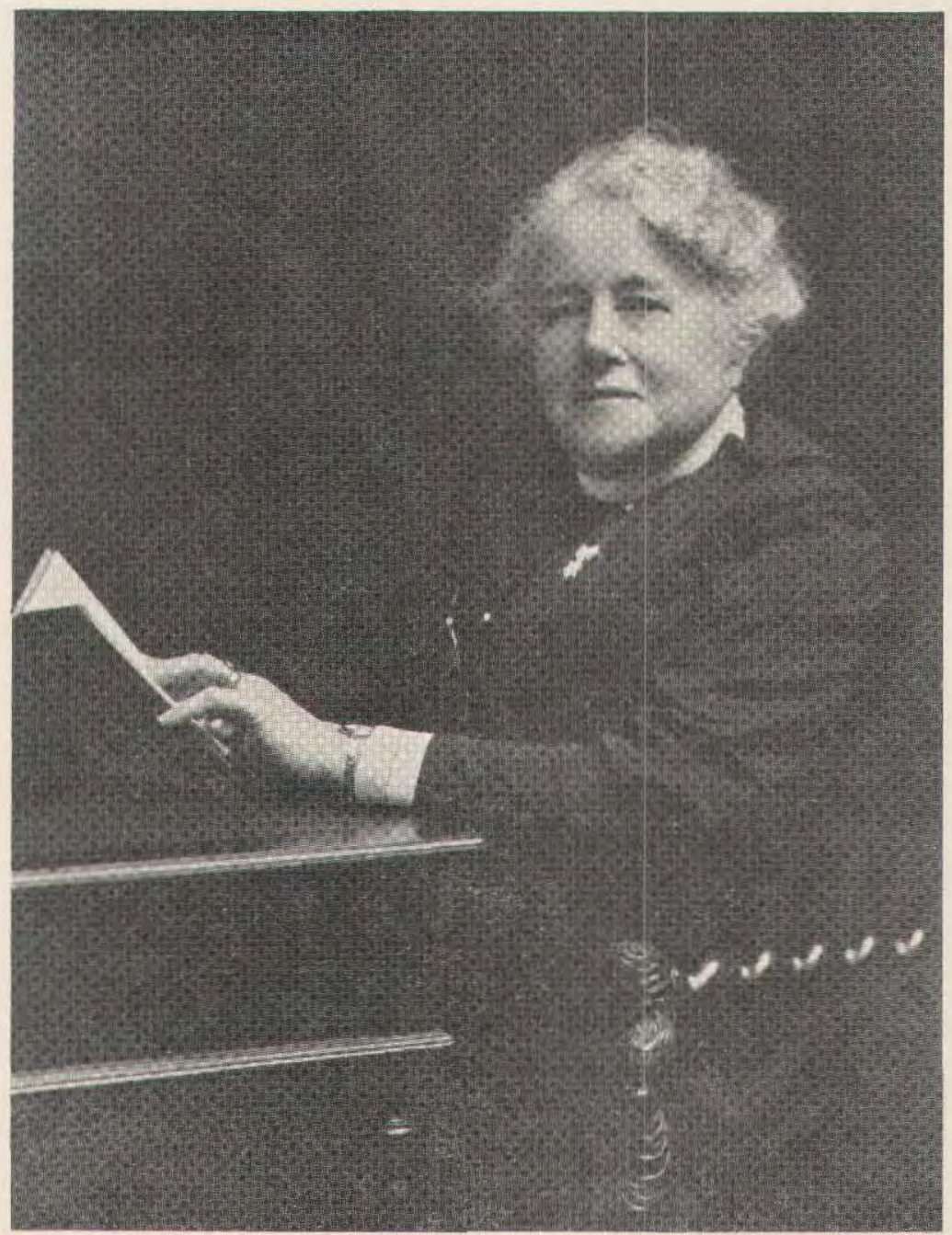

MARY ANN MORRISON (Nee GRACE) FROM GUERNSEY

Married 13th September 1883

In the month of June 1881, the Staff Officer, Army Hospital Corps came to Netley to verify the Corps Records. I brought to his notice the grievance of my quartermaster sergeant, Staff Sergeant Vale. He had qualified for a commission and was recommended 
by His Commanding Officer, but when he was ordered to South Africa for duty, his Commanding Officer reported him as being in a delicate state of health and at the time unfit for foreign service. The real reason was that the Commanding Officer knew a good non-commissioned officer and was anxious to retain his services. His name was struck off a list of selections for a commission.

He had in his possession a letter from someone, who posed as having in his power the bestowal of a commission on payment of a fee of $£ 50$. Not having had such a communication myself before receiving my commission, I doubted its authenticity, but grieved to find that such a document existed. I suggested to the staff officer that the mysterious patron should be unearthed and brought to justice. I was told not to trouble myself about such a report as it did not concern me in the least.

I had previous to this recommended my quartermaster sergeant should be granted an extension of service for another five years. He was certainly the best non-commissioned officer I ever had. He was not an eye servant, and was most reliable. In the Establishment like Netley such a trustworthy man was invaluable. On the return of the staff officer to London, instead of sanctioning the extension of service asked for, an order came to discharge him forthwith. He had given offence and the man who would dare to expose his soiled linen to the Public gaze must be sacrificed.

On the first of July 1881 a Royal Warrant was issued prejudicial to the status of the officers of the Army Hospital Corps. They were arbitrarily deprived of their combatant rank and status by the Director-General and transformed into departmental officers with relative rank only. Against this retrograde action an appeal was made to The Horse Guards through the Director-General. The new title of "Quartermaster" in lieu of "Captains and Lieutenants of Orderlies" was objectionable in the extreme. The new title was obnoxious for various reasons. Our commissions were combatant, while the Quartermasters were "Honorary" a term described by philologists as " the shadow of a rank" (W.K.M. A most charming Commanding Officer of mine, a regular, a Lieutenant-Colonel R.A.M.C. always referred in November 1914 to quartermasters as " quartermongers").

A non-commissioned officer or warrant officer who could produce a second class certificate of education was at the time eligible for a quartermaster's commission, while lieutenants of orderlies commissioned after the first day of January 1879 had to pass an examination in Pharmacy, Drill, Physiology, Interior economy, Military Law and a general knowledge of the Regulations of every Branch of the Service, and on this ground alone, if on no other, we were by the uses of the Service entitled to more equitable consideration. Our duties had nothing in common with regimental quartermasters, we were apothecaries and sub-accountants.

We were unrepresented in Parliament and friendless at the Horse Guards and had to accept what the Director-General chose to give us. The usage of the Service, when new Regulations were promulgated, has been to conserve the interests of officers concerned, and not until Medical Officers began to frame Royal Warrants was this righteous rule wilfully violated. The captains of orderlies were determined to persist in their effort to retain their military rank with the increase in pay proffered by the new Warrant. Their relative allowances could not be withdrawn, a sore disappointment to the medical officers who framed the warrant. They formed a committee to safe-guard their own rank 
and privileges. They were ready to sacrifice the lieutenants on the altar of selfishness, maintaining that we had no grievances, that in Society we had no rank while they were "Captains" notwithstanding the tail of "Orderlies". The Director-General was most emphatic in his refusal to entertain their complaint.

To emphasise his dislike to the men whom he had commissioned he refused to put us on the same daily rate of pay as the Quartermasters of the Army Service Corps, Royal Artillery, Royal Engineers and Ordnance Department, relegating us to the lowest rate he could find, the Regimental Quartermasters. To this he was cordially aided by the officers who framed the warrant.

Personally I must admit that the selections to commissions were unfortunate and inexplicable, but educationally they were far in advance of the majority of the regimental quartermasters with whom I came in contact in my wanderings, one of whom I heard relating a grievance against the War Office. He had appealed against a decision of the Accountant General's and was informed by the Secretary of State for War that his appeal could not be entertained. He was loud in his denunciation of the injustice, adding that "the fellow who signed the refusal hadn't the courtesy to sign his full name but signed himself as " Hartington " only. I had difficulty in persuading him that the signature was that of the Secretary of State for War.

Failing to obtain redress from the Director-General, I interviewed the Financial Secretary, Henry Campbell Bannerman, Esq., M.P. at the House of Commons with a letter of introduction from Sir Henry Havelock-Allen, Bt., V.C., an officer who stood by my brother's side when General Havelock recommended him for the Victoria Cross (W.K.M. His brother Hugh of the 78th Foot died of wounds 17th September 1857 at Lucknow. His name appears on The Seaforth Memorial on the Edinburgh Castle Esplanade):

I was received very cordially and on stating my case he frankly told me that the War Office was prepared to place us on the same rate of pay as the Quartermasters of other Departments, but that the Director-General would make no concession in that direction. He recognised that our duties as Sub-accountants and Apothecaries should certainly have secured us more favourable terms than the Director-General felt disposed to give us. Finding the Director-General unreasonable and obstinate, the Committee sought to coerce the junior ranks into refusal of the Warrant. To this I offered an uncompromising opposition, and sought the co-operation of Lieutenant Robert Gordon to thwart the designs of the Captain of Orderlies. I saw no reason for refusing the financial provisions of the Warrant, much as I detested the assumption of a title foreign to the nature of my duties. Gordon and I accepted the Warrant and were accordingly Gazetted. The Committee denounced us as traitors, while the Staff Officer was accused of having informed his fellow partners in rebellion, that the extra pay would not serve us much, as he would keep moving us from station to station until we repented of our action.

No sooner were we gazetted than I was ordered to the Curragh Camp. I was but a few weeks there when I had several letters from Lieutenants of Orderlies asking me to appeal to the Director-General to allow them to accept the Warrant. One who had applied had been refused. Feeling that while the Staff Officer of the Corps was allowed to retain his position at Headquarters, the officers who had accepted the Warrant would have rather a tough time of it. I wrote to the "Broad Arrow" in April 1882, detailing 
the proceedings of the Coercion Committee and at the same time indicating to an officer on the Director-General's staff that six of the Lieutenants were desirous of accepting the new Warrant. I was informed in reply that if they applied by letter each case would be considered on its merits. In the course of a few days they were all Gazetted.

Meantime the Staff Officer was returned to Hospital duties, being replaced by Surgeon Major S. Clarke, M.D. from the Sanitary Branch of the office. This was an unexpected blow to the Coercion Committee and the cleavage in its adherents soon became apparent. One by one they applied for the new Warrant notwithstanding the virulence with which those who refused to support them were assailed.

For several years, one solitary individual, who swore he would never be labelled a "Quartermaster" remained in the Army List having a section to himself, but at last found that however hateful the title, the financial prospects of his combatant rank warrant compared unfavourably with the new, and he forsook his perch to participate in the good things of the despised warrant and became a "Quartermaster".

Before leaving Netley for the Curragh; I wrote to the Senior Medical Officer there asking him to apply to the Royal Engineers to put the Lieutenant of Orderlies hut in Hare Park into such repair as would make it habitable. This the officer Commanding Royal Engineers declined, urging as his excuse that he had no funds. On my arrival I declined to take it over. Captain Colebrook of the Commissariat Staff supported me in my refusal, admitting that the hut was wholly unfit for occupation and gave me one end of his own hut until such time as the Royal Engineers recognised the justice of my appeal.

I informed the Senior Medical Officer that I would not take possession of the hut, and asked that a Board of Medical Officers be detailed to report on its condition. Meantime I suggested that he should accompany me to the Royal Engineer's office that I might plead my own cause. Accordingly we wended our way there and renewed the appeal. The C.R.E. was not prepared for the storming of his citadel and testily replied "I told you already that I couldn't touch that hut". Crestfallen Dr. Ekin was about to retire from the scene when I asked the C.R.E. if he had seen the hut. To this he replied "I have not ", raising his eyes from his desk, with a surprising look asked "Where have I met you before?". I replied "At Netley when you returned from India ". "O! It was you who assisted me to collect my black bags". I replied that I was the same. Immediately he rang his bell and summoned Captain Grieve and instructed him to proceed to Hare Park Hospital and set the Foreman of Works to put the Lieutenant of Orderlies' hut in good condition and fit new appliances where required, and make it as comfortable as possible, charging the expenditure to the following year's accounts. The hut was soon put into order and for comfort was second to none at the Camp.

The C.R.E. had returned from India in charge of troops a few months before I left Netley. He was granted a troopship for his wife and family on condition of taking charge of the troops embarking at Bombay and to hand over the invalids at Netley. On reaching Portsmouth, a new order regarding the men's kitbags was put into his hand, directing the return of the kitbags into store for re-shipment to Bombay, all deficiencies to be paid by him. This was rather hard on the officer who took the men home, as on reaching Portsmouth the men were sent to three different stations, Woolwich, Netley and the Discharge Depot in one of the Portsmouth Forts. Like every ill-con- 
sidered order, this was impossible to carry out. The men had to carry their kitbags to the Depots, or purchase a bag in which they could carry their kits. At Netley alone could this order be carried out.

Previous to this, the kitbags were the men's own private property. No sooner than they were discharged from the Service than they purchased ordinary bags with which to start for home, consigning the old kitbags to the dust cart. Hearing that such an order was to be issued, I kept the bags the men threw away so as to make up deficiencies in the year's incoming drafts. It was this that led to the incident of the black bags that gave me a restored hut.

As soon as I was settled in my comfortable quarters I took over the stores from the officer who had nominal charge. These were in such a chaotic state as to defy taking over from the existing inventories. Assisted by Barrack Sergeant Davis, a good soldier of the Cameron Highlanders, I set about making an inventory of what were actually in the wards and stores, finding that $I$ had a deficiency of about $£ 250$ worth of stores, and a surplus of over $£ 350$. On representing this to the Senior Commissariat Officer, he expressed thankfulness that I came to the station before Sir Edward Morris made his Annual Inspection. Sir Edward Morris was trained in the Purveyor's Department and knew how to examine stores, a qualification which fell to the lot of but a few of the Officers of the Commissariat Department of those days.

I received very considerate and courteous assistance from Brigade Major Ekin in carrying out my duties. I was not there very long until I found out how essential it was to have an officer there to superintend the working of the Hospital. The nursing sisters there, as elsewhere, thought that there should be no restriction in the waste of medical and surgical appliances and resented the curtailment of what I thought was absolute waste.

Non-commissioned officers over whom there had been no disciplinary control for some time resented being pulled up and for a time felt disposed to obstruct in every possible way. Few medical officers of the pre-combatant era cared to be harrassed with the practical details of Hospital Administration. The Wardmaster in Hare Park Hospital had his own quarters well furnished from the wards, while the sick were deprived of arm chairs and other comforts by the man who above all others should have looked after their interests. I reported this irregularity to Surgeon Major Wikley, who peremptorily ordered me to inspect none of the wards without his authority. I pointed out to him that I was in charge of the stores and the discipline and cleanliness of the wards and would at once report his obstruction to the Principal Medical Officer.

Next morning Dr. Ekin sent for him and informed him that he was to assist, and not to obstruct me in the performance of my duties. A few days after this incident, on visiting the hospital kitchen after the dinner hour, and on inspecting the kitchen drawers, found a leg of mutton concealed in the corner. On asking for an explanation from the cook he informed me that the steward gave it to him instead of beef to make beef tea. This the steward positively denied.

I transferred the cook from the Cookhouse to the Guard Room. On reporting the matter to Surgeon Major Wikley he ordered me to release the man and return him to his duty. This I declined to do. I told him that he might deal with the case as he pleased, but the crime must be recorded and he could not be taken back to the cookhouse. He was more solicitous for the reputation of the Army Hospital Corps than for honesty 
and efficiency, and to prevent a scandal he sentenced the man to seven days confinement to Barracks, altering the crime from " misappropriation of patients' diets" to "neglect of duty" so as to hide the nature of the crime. Next day the cook in the First Station Hospital applied for transfer to Dublin fearing that he might be caught in the same discreditable practice.

While stationed at the Curragh, an amusing incident came under my notice emphasising the dissatisfaction of the married families with the unification scheme that deprived them of the services of their own Regimental Medical Officer. The wife of the Sergeant Major, Durham Light Infantry had occasion to send for the medical officer in charge of families. On presenting himself at her Quarters, she apologised for the trouble she gave him, and bluntly informed him that she had never called in an Army doctor before, but being three miles from a civilian doctor, she was reluctantly compelled to send for him. He listened to her harangue in silence, prescribed for the child, and hurried to my quarters to relieve his outraged feelings. I could not but respect her outspoken bluntness and remarked that her misfortunes had drawn from her unpleasant truths in which the whole of the married establishment of the British Army concurred. She had no respect for the men who threw aside the 'Lancet' for the 'Drill Book'. Mrs. Thomas Atkins had lost faith in the militant doctor (W.K.M. In 1923, for a short time I did duty in the R.A.M.C. "Panel' at Woolwich Arsenal, which looked after more than 6,000 civilians working in Woolwich Arsenal. A civilian named Rook was brought in one afternoon with a very slight stroke. I sent him home and going to call on him next day at his home in Plumstead, I was surprised to see the name plate of a general practitioner on either side of his dwelling. I said "Mr. Rook I see you have two doctors near yet you remain on our panel". He said "Yes! but I was a gunner in the Army and I was so well looked after that naturally'I prefer to continue to be looked after by the Army doctors". In the Royal Herbert Hospital at that time there was a very fine Commanding Officer, a one-time Family Specialist, of which category of specialists very many excellent family doctors could always be found (The Commanding Officer was Colonel V. J. Crawford). $I$ went into the mess after seeing and hearing Mr. Rook and in my unfortunately loud voice, told my special friends this story, saying it was rather wonderful to hear such high praise for the R.A.M.C. Colonel Crawford came across the room and pointed out how wrong.I was in not fully understanding that in our medical service and in our hospitals the soldier always had the benefit of quick attention and consultations with the various specialists.

This reminded me of how a civilian was travelling along a road in Aldershot in 1930, when an Army cricket ball came through the window of his car and striking his ear led to a violent haemorrhage, he came to the outpatient surgery and in a few minutes was seen and adequately dealt with by the E.N.T. surgeon Major (Tiny) St G. E. Harris on a Saturday afternoon. The civilian expressed his appreciation at such efficiency).

Immediately on the assumption of the duties of Staff Officer at the War Office, by Surgeon Major Alfred A. Clarke, I was ordered to Dover for duty. My removal from Netley to the Curragh was an act of the grossest cruelty and injustice on the part of the Staff Officer, Captain David Pringle on the suggestion of the Coercion Committee: My wife had previously undergone a severe operation from which she never recovered, and her removal to the Curragh caused her much suffering. Her condition was well known to the Staff Officer who had visited Netley a few days before the Committee began their agitation, the coercing power behind him was too strong to allow the 
exercise of any benevolent feeling that might have survived my acceptance of the objectionable warrant.

Six weeks after my arrival in Dover my wife died, the journey to and from Ireland have aggravated her complaint. Thus I was deprived of the companionship of one who, for eighteen years of a happy wedded life, gave a life of unselfish devotion, of a saintly character and christian consistency in her home and in a circle of a large and varied field of christian usefulness.

I had just completed taking over my Sub-District when the Egyptian troubles of 1882 broke out. I was directed by telegram from the War Office to take over the duties of District Officer and also Sub-District No. 2 in addition to my own duties. The officers concerned having been ordered to Egypt. Twenty-four hours after taking over the District Officer's duties, a telegram from the Director-General ordered two sergeant majors and thirty non-commissioned officers and men to proceed to Aldershot at once for duty with the expedition. The Principal Medical Officer, Deputy Surgeon General James Hanbury was on inspection duty in Shorncliffe: the telegram was urgent and could not be delayed until his return next day. He had no Deputy and I had to act at once. I selected the best and most reliable in the District dispatched warrants to medical officers at the various stations and telegraphed to send the men to Aldershot by the early train. The Senior Medical Officer, Shorncliffe on receiving the list of names selected, resented the removal of the best men in the Hospital and having the Principal Medical Officer on the spot, appealed to him to avert such a calamity. The Principal Medical Officer wired to me "Have these men been detailed from London, and if not, by what authority have you selected them?'”

To this I replied "These men have not been detailed from London, I have selected them under the authority vested in me by the Army Hospital Corps Regulations. Please do not alter the detail. Warrants filled in. Pay Ledgers closed. Will be in Shorncliffe 8 a.m." On the Principal Medical Officer's return he called at the office and instructed. the clerk to acquaint me that he was in the office and wanted to see me. He was informed that I was in Shorncliffe and would not return before midnight. His rage was unbounded, but he left the office reserving a portion of his execrative adjectives for the following morning. During the night he was detailed by telegraph to accompany the expedition as Principal Medical Officer.

Next morning he was at the office at an early: hour and complimented me on the expeditious manner in which I had acted, and especially in having selected the best men in the District for active service. Had he not been detailed for this active service with the expeditionary force, my early morning's reception would probably have been of an entirely different characier. It would have been " the Curse of Crummel " rather than a benédiction. Each week brought fresh demands for men until only a few trained orderlies were left in the larger hospitals. Pensioners and regimental men were substituted for trained orderlies.

Hearing of the difficulties in the wards with untrained men, I suggested to the acting Principal Medical Officer that there were trained orderlies employed as grooms, gardeners, messéngers etc; while untrained men from the regiments were looking after the sick. An order was issued withdrawing trained orderlies from the duties to which they were irregularly appointed. For this I incurred the displeasure of the Senior Medical Officer for depriving him of his groom. 
I had occasion to call on the Staff Officer Army Hospital Corps hoping to prevent three of my best orderlies being transferred to the Reserve. He declined my request saying that he wanted to form a Reserve for the Corps. I suggested a Militia Army Hospital Corps should be formed and trained annually at our large hospitals. I tried to impress on him that it would be better for the Corps that men going to the Reserve, where they now got no further training would benefit by annual training with the Militia.

A few months after the departures of the fire-eating Surgeon General Hanbury, a Principal Medical Officer joined from India, who had not previously administered a Home Station. He was a novice in administration. Anxious to conciliate the members of the Department he sought advice from them all, and like the man in the fable who was leading home his ass, did not benefit from the mixed advice given him.

His appreciation of the professional attainments of the members of his Department was not very flattering. He had been told that I had invariably acted as chloroformist for Surgeon Major D. Blairbrown and stormed at the audacity of Dr. Brown daring to operate without first consulting him. I incautiously remarked that Dr. Brown was one of the most capable operators in the Department and referred to a most successful case of carcinoma performed by him. At this he flew into a rage and said " if I had the itch or any of the other common ailments perculiar to a soldier, I would consult an Army Medical Officer if compelled to do so, but for nothing else." I quietly informed him that he should be the last to enunciate such an opinion. I could not help regarding him ever after with supreme contempt.

Having made a minute inspection of every hospital in the District, I reported rather unfavourably on their equipment and particularly on the laxity of the Commissariat Department in replacing stores charged against the troops giving full details in every instance. In some of these cases articles that had been paid for eighteen months previously had not been replaced. I suggested to the Principal Medical Officer that before passing my report to the Senior Commissariat Officer he should verify my complaint at his inspection of the Western Heights and Shorncliffe Hospitals. This was done and then my report forwarded. A few evenings after he met Commissary General Fulford Adams in the Club, who requested that he should withdraw the sweeping condemnation of the Commissariat in the Quartermaster's report, promising to rectify things at once.

The War Office arrangements for the Brighton Volunteer Review of 1883 having been completed, a missive from the Director-General directed the Principal Medical Officer to represent the Department at this function. I was instructed by the Principal Medical Officer to arrange with Surgeon Major Wilson to provide him with a mount worthy of the occasion and a room in the Hotel. The arrangements were completed when the wife interposed and vetoed the compulsory presence of her Lord in a saddle. She conceived the idea that some rhymer might be found to attempt a new version of John Gilpin's famous equestrian display. As he had not mounted a steed for thirty years, but had been drawing the equivalent of forage for two horses for many years, it was certainly a little embarassing. I suggested a four-wheeler as: a suitable mode of transport. This was a humiliation to which he would not agree.

Suggesting that instead of a gambol across the Brighton Downs, a few days rest 
on the ever accommodating sick list might tide him over the difficulty. Accordingly he placed himself on the-couch, reporting himself to the War Office as unequal to the honour conferred on him. Thinking that this was an opportunity to put him on the retired list, an unusual order was issued for him to be brought before a Medical Board at once. A complacent Board certified his unfitness to take the field, but guaranteed his restoration and resumption of duty by the time the military display at Brighton came to an end.

The removal of the senior non-commissioned officers from the District for service in Egypt left me with a questionable staff in all save Canterbury. Hospital. I had reason to believe that pilfering of the patients' rations was resorted to and I determined to fathom its mysteries. The Steward was a pensioner of the Corps, a sergeant whose antecedents did not justify his employment in that capacity, having spent his whole service in the Clothing Stores. The Wardmaster was equally useless particularly as a disciplinarian. I completed my weekly inspection of the stores early one day and asked Surgeon Major Guiness to accompany me to the cookhouse. He asked if $I$ had anything in particular to show him. That I remarked depends on the circumstances. On examining the boiler containing the beef tea, I found the bones from the previous day's roast and a few scraps of meat as the basis of twenty pints of beef tea. Turning to the cook I asked where the eleven pounds of beef that should have been in the boiler had gone? He replied that he had received none from the Steward.

I sent for both the Wardmaster and the Steward, but no amount of cross-examination could elicit the truth. " Craws winna pick oot craw e'en " was the only natural conclusion at which I could arrive. A " pot de foie" had been kept simmering on the kitchen range into which bones and scraps, with some gravy and burnt sugar found their way to produce a concoction that passed for beef tea, while the beef found a ready market.

As the discipline was in the hands of the medical officer the cook escaped with a nominal punishment of seven days confined to barracks, no doubt congratulating himself on his escape from a Court Martial and inwardly invoking a blessing on the functionary who had taken the disciplines of the Ärmy Hospital Corps from the officers of the Corps and placed it in the hands of the medical officers. The Steward being a pensioner, was under my orders and was summarily dismissed.

On my inspection of the Canterbury Hospital I made a minute inspection of the contents of the various vessels on the range, and was informed by the Wardmaster that I would not find what I had found in Dover. I asked what information he had on what I found in Dover. To this he replied, that I had not been three hours out of the hospital there when it was known in every hospital in the District. It is curious how thin a veneer covers the unregenerate man, when the question of money is involved.

A medical officer brought me a travelling claim for adjustment and initialling before he brought it before the Principal Medical Officer for signature. I had to apply the pruning knife unsparingly, adding a short homily on the certificate printed on the War Office form in justification of the reduction. He took up his claim and left the office dissatisfied with his reception. He went into the adjoining office, rewrote his claim and wended his way into the Principal Medical Officer's quarters, urging the plea of extreme urgency to get his money. On presenting it to the Station Paymaster the pruning knife went over the same field, but from this there was no appeal. He came back extremely. disappointed and informed me that he had made out another claim but that the Pay- 
master had struck out all that I had put out, remarking "I could not expect anything better from him, he is a ranker ". I thanked him for the compliment to the ranker's sense of honour and informed him that, as a rule "rankers" knew their duty, adding that if he had been unfortunate to have entered the ranks he would have remained there. Feeling that I resented the reference he remarked "I am not personal ", to which I could only reply that he was to regard the expression of my views as exceedingly personal. We were nevertheless ever afterwards the best of friends.

The treatment handed out to a "ranker" in a Regiment of Foot then stationed in Dover was peculiarly characteristic of the snobbery of the general run of British Officers. The Quartermaster had recently joined from another Corps as the Colonel of the Regiment refused to recommend any of his own warrant or non-commissioned officers for the vacant quartermastership. He came to the Regiment bearing Her Majesty's Commission, the same impress that gave social currency to a comparatively large number of those commissioned through the Militia and through the Civil Service competitions. The officer on joining paid his subscription to the Mess and to the Band funds on equal terms with the others joining at the same time. From the commencement he was made to feel that he was an "undesirable" and every opportunity was taken to make him feel his isolation. A Mess Meeting was summoned in Regimental Orders. The Quartermaster attended as a subscribing member, when he was told by the Colonel that he was not wanted there. At a Garden Party the Surgeon and the Paymaster, neither of whom were subscribing members, were invited, but apparently the Quartermaster was not eligible for a Garden Party in his own Regiment.

On the following day the Quartermaster appealed for redress to the man who had so insulted him, but instead of redress, was told that he would be expelled from membership of the Mess. He then appealed to General Newdegate, Commanding the District, who after consultation with the Colonel of the Regiment, declined to submit the matter to the Horse Guards. A few weeks afterwards the Quartermaster was retired on the pension of a Sergeant-Major. So much for the justice meted out to the weak in the commissioned ranks of the British Army (W.K.M. In a recent television play "The Regiment" the statement was made that in former times "Rankers" had a very bad time. in the Army, now it was all different).

When the "Morley" Committee was sitting in judgement on the shortcomings of the Army Medical Department after the first phase of the Egyptian War, I had a note from Miss Florence Nightingale informing me that Sir Robert Lloyd Lindsay, V.C., M.P. (subsequently Lord Wantage), who had some time previously accompanied Sir W.M. Muir to Netley and to whom then, I was asked to explain the general routine of work throughout that Hospital, expressed a wish to see me with reference to questions that had arisen at that Committee of 1882 , of which he was a member.

I arranged to meet Sir Robert in London and for three hours discussed with him various points bearing on the administrative and executive branches of the Army Medical Department, with particular reference to the period preceding the unification scheme. Having served in the Department for ten years previous to the destruction of the regimental hospitals, I was fully convinced of the superiority of the old over the new order so far as tenure of office of the Regimental Medical Officer was concerned. 
The doctor was then the guide, counsellor and friend of the officers, the men and women, and no father confessor was ever entrusted with more secrets than the majority of the regimental doctors. I strongly advocated his restoration, but keeping the Station Hospitals on the new basis.

We next discussed the abolition of the Purveyors' Department in the general departmental scramble of 1870 with its insane arrangements for hospital supplies through the Commissariat Department, remarking that I had never known a Purveyor to be cashiered for misappropriation of hospital supplies, but that I had seen two commissioned officers of the Commissariat cashiered for tampering with hospital supplies under the new management. I strongly advocated that hospital supplies should be in charge of an officer under the control of the Principal Medical Officer, freed from every connection with all subsidiary departments except the Ordnance Department from whom supplies could be received in peace and in war.

I brought prominently before him the absurdity of keeping up non-dieted hospitals as an injustice to the patient who could never have the comfort or attendance to which a sick man was entitled. The next item was the District Surgical Equipment stored in the Principal Medical Officer's office and issued on requisition to outlying hospitals. In no instance were there two articles of a sort in this Equipment. With thirteen or more hospitals in a District, in some instances these hospitals would be one hundred miles apart, and five or six of them requiring a particular instrument at the same time, the system condemned itself.

I next suggested the transfer of the Army Medical School from Netley to London (The Director-General, Sir Thomas Crawford, would have had it there but the idea was considered utopian), or Woolwich. This amused him very much. "What" he remarked " Remove Sidney Herbert's memorial to London?"

I urged him to take up the question of the training of military dispensers of medicine, pointing out that the present system was imperfect and highly dangerous. The man anxious to qualify as a dispenser had to do so in addition to his ordinary duties and at his own expense supply the necessary books. When he committed to memory the doses, the preparation of tinctures, pills amd powders, he was deemed to be a qualified dispenser. The consequence of his training inside the Service, is that however efficient a military dispenser he has become, he cannot be employed as a dispenser outside the Service. I pointed out to him the privileges enjoyed by dispensers in the Indian Medical Service in having a two-year course of study in a Medical College.

I suggested that such of the Staff Sergeants of the Army Hospital Corps as could pass the Preliminary examination of the Society of Apothecaries should have similar training to the Indian apothecaries at the Army Medical College. This he was afraid the Treasury would not sanction the expenditure. Turning to me he asked "How would you meet the expenditure?" To this I replied it could be done by abolishing the present system of so called "good service awards" and annuities given to officers and noncommissioned officers, not for the performance of duty more than there less favoured comrades, but because they have more friends in power.

Having discussed every conceivable item of hospital administration, he remarked "You must have made hospital work your life study". I replied that I had just completed twenty years hospital experience in its various subordinate grades and a short experience at the War Office. Both Sir Robert and I regretted that the last evening train for Dover was almost due to leave the station. 
In the religious life of the Dover Garrison I was debarred from much regular work owing to the frequence of my absence from home on inspection duty. In temperance work however I had frequent opportunities of leading men of our own Corps to become abstainers. A sergeant of the Corps, whom I persuaded to give up his drinking habits, entered into the campaign with enthusiasm. Two months after his reclamation he marched twenty-five of his co-religionists to the altar in the Roman Catholic Church in Dover to sign the pledge of total abstinence.

Towards the end of September 1882 I had an invitation to visit Mr. and Mrs. W. D. Atkins, friends of mine, for the week end in Shepherdswell. I was asked to take on Evening Service in their Wesleyan Chapel. On the following Wednesday the Superintendent, the Reverend George-S. Tyler asked me to take a service early on the Sabbath. Having for fifteen years declined to take up the office of a lay preacher. However, thanks to my class leader, Mr. George Flashman and Mr. George Clark I became a licensed lay preacher in the Methodist Church.

From its inception the Methodist Church manifested an interest in the religious life and work of the soldier. One evening at my class leader's home, we had a discussion with the Prince of Controversialists the Reverend Dr. George Osborne, I remarked that Scotland was the only unproductive soil that had come under my observation. $\mathrm{He}$ acknowledged that Armenian Doctrine was peculiarly obnoxious to the Scottish character. Whatever service I may have rendered to the Church and Christian work in general, since 1882 had its stimulation in Mr. and Mrs. W. D. Atkin's home in Shepherdswell.

Having now had over sixteen months in the District, inspecting twelve hospitals twice every three months, I suggested to Surgeon Major William Johnston, Staff Officer Army Hospital Corps that these inspections should be reduced to one every six months and that to be a surprise visit. He said "The officers like these inspections " and indicated that he was thinking that the Army Hospital Corps officers wanted them from a profit motive. I replied that I was not thinking only of the Army Hospital Corps officers, but also of the Army Medical Department and chiefly of the tax payer, in whose interest a change was essential. Sir Thomas Crawford after his inspection ordered this change to take place.

Being placed under orders for foreign service, I re-entered the matrimonial state, having on the 13th September 1883 married in Eldad Congregational Church, Guernsey, Mary Ann Grace the youngest daughter of Captain James Grace of the Mercantile Marine and Senior Deacon of the Church. The Minister and the poor particularly resented my invasion of their fold, the former having deprived him of his most energetic worker both in the Church and the Sunday School, and the latter for the loss of their best helper and friend.

On 17 November 1883 I embarked at Southampton on board the Royal Mail Steam Packet "Don" for Barbados. Among the friends I said good bye to that day, was one that shall ever remain dear to my memory, after a genuine friendship of nineteen years, begun at Netley in 1864 and ended at Netley in 1883. John Mullins was worthy of a sacred niche in the hearts of those who knew him. He fell a victim of enteric fever in the Egyptian Campaign of 1884. Lieutenant Mullins was a loss to the Army Hospital Corps. Had those selected for commissions in the Corps been of his type there would have been fewer relegated prematurely into obscurity. 
The passage to the West Indies is the most unromantic and uninteresting on which a soldier embarks during his service. After leaving sight of the Cornish Coast nothing of special interest is seen until sighting Teneriffe. A ship may hover now and again in sight, when the loan of your field glasses may extract an exchange of words with one or more of the motley throng that swarm on deck after the card tables are cleared (W.K.M. I can remember sometime about 1910 my father came into the upstairs lounge and found my sister playing whist with three friends, in anger he, with exceptionally strong hands, tore up the cards and forbade such things ever to be brought into the house again).

The impecunious are intent on making daily sweepstakes on the distance run by the ship in twenty-four hours, or on the probable number of ships seen by the look-out in the same time. Of the 350 passengers on board, 300 were colonials returning home after a sojourn of between three and six months in Great Britain or on the Continent.

If these were genuine samples of the West Indian plutocrats, I am not surprised that the negro should have made so little progress in the ascending scale. Gambling and drinking seemed to be the stock enjoyment of these pleasure-seekers. The drinking bar was open from early morn to midnight. No wonder ship stewards can retire to their comfortable villas early in life.

On the fourteenth day the "Don" cast anchor in Barbadian water, a general chorus of thanksgiving greeting the splash. Landing at the Commissariat Pier I had to wend my way in search of lodgings. There was no hotel in the neighbourhood and no quarters for Junior Departmental Officers. Generals, Commanding Officers and Heads of Departments are sumptuously provided not only with castles, but with several acres of land and military labourers to work the same. Juniors must shift as best they can. Their chiefs are well provided for.

On the Sunday after I landed in Barbados, a deputation for the Presbyterian noncommissioned officers and men of the "Royal Scots " headed by the Armourer Sergeant came to my quarters to request that I might arrange for non-liturgical service for the four hundred Presbyterian soldiers neglected by the Church of their fathers and refused redress by the Officer Commanding their Regiment. They objected to be marched to the Government Episcopalian Church in Barracks; the same objection applied to the Wesleyan Methodist Church where Wesley's abridged Liturgy was used at the morning service.

I communicated their scruples to the Acting Wesleyan Chaplain, asking if he could conveniently undertake a non-liturgical service before the ordinary service provided the sanction of the General-Officer-Commanding could be obtained. Instead of replying to my letter he called on the Adjutant-General (Colonel Justice) and gave him a private letter never intended for the latter's scrutiny. This was resented in a spirit worthy of the old persecutors of the Scottish Covenanters.

This modern champion of the Tractarian movement would not respect the conscientious objections of John Knox's children and determined to nip the proposal in the bud. Accordingly a memorandum to me, under cover to my chief, Deputy Surgeon Holten informed me'that the Sabbath Services for the Presbyterian soldiers had the approval of the General-Officer-Commanding and that $I$ was not to interfere with the existing arrangements, as these were made with the concurrence of the Officer Commanding the Regiment, who was an Episcopalian, at the same time propounding the novel doctrine that the General-Officer-Commanding had as much right to arrange for the spiritual 
as for the temporal requirements of the soldier. I replied that the provisions of Queen's Regulations on this subject were decidedly antagonistic to this view, suggesting that application be made to the Convenor of the Army and Navy Committee of the Church of Scotland to send a Licentiate of the Church of Scotland to officiate in the Garrison during the residence of so many Presbyterian soldiers. To this a very curt reply was given.

I was determined that having entered on the campaign for religious liberty, I would not relinquish the game until I succeeded or was silenced. After thirteen memorandums had passed between us, I was ordered peremptorily to cease the correspondence. Failing to overcome the prejudices of the Adjutant-General I sent a copy of the correspondence to Mr. Charles Fraser-Mackintosh, M.P. for Inverness-shire, who interviewed the Secretary of State for War after reading bits of the correspondence in the House of Commons. The Secretary of State for War directed the General-Officer-Commanding the West Indies to arrange a non-liturgical for the Presbyterian soldiers forthwith. On receipt of this order a memorandum was sent to all the Scottish officers in the Garrison calling for volunteers to read prayers to the Presbyterian soldiers. They all declined the service, one of the Majors of the Royal Artillery in recording his refusal added " preaching is not in my line". The duty was eventually undertaken by the Acting Wesleyan Chaplain in addition to his own ordinary services.

This catholocity of spirit was, sneeringly, resented by the Garrison Chaplain and referred to as " a catholicity based on the hard cash drawn from the Pay Office for the performance of this particular duty". Had he been trained in the same theological school as the catholic minded Wesleyan chaplain, he would not have had to complain that the soldiers were impervious to his teaching, and that from hardness of heart they under-valued his ministrations.

I have frequently listened to rapturous encomiums on his admirable handling of the tennis and cricket bats, but never a word on his success as an expounder of the doctrines of salvation through faith in a crucified Saviour. In the exposition of the story of the uplifted Cross of Calvary the Wesleyan chaplain was a decided success.

It was my privilege while this outburst of sectarian animosity was being fanned into a flame by the intolerant Adjutant-General, who unfortunately belied his pateronymic, to conduct occasional services for the rector of St. Paul's in one of his missionary halls, with the concurrence of the Bishop of the diocese, to emphasize that fact that my objection was not to the services of the Church of England, but to the indifference of the Military Authorities with regard to the spiritual oversight of the Presbyterian soldier.

I soon experienced the intolerance of the Adjutant-General arising out of this incident. The gentleman became obscured in the sectarian bigot (W.K.M. Hart's Army List examined at the excellent library in Edinburgh Castle shows "Colonel W. C. Justice, C.M.G., A.A. and Q.M.G. Barbados 1883 ". He served in the 75th Regiment, the Gordon Highlanders, 1857 during the Indian Mutiny. Also saw much active service).

(to be continued) 